\title{
Immunisering i svangerskapet
}

\author{
For 40 år siden ble IgG anti-D tatt i bruk som profylakse mot Rh(D)- \\ immunisering. Det er nå på tide å revidere programmet for forebygging \\ og overvåking av immunisering mot blodtypeantigener i svangerskapet. \\ Det er også mye som taler for at tilsvarende program bør utvikles for \\ immunisering mot trombocyttantigener, især HPA-1a. Vi trenger en \\ nasjonalt koordinert innsats i forskning, forebygging og klinisk arbeid.
}

\section{Hans Erik Heier}

h.e.heier@medisin.uio.no

Avdeling for immunologi og transfusjonsmedisin Oslo universitetssykehus, Ullevål

0407 Oslo

og

Det medisinske fakultet

Universitetet i Oslo

\section{Lillian Nordbø Berge}

Kvinneklinikken

Oslo universitetssykehus, Ullevål

\section{Tor Hervig}

Avdeling for immunologi og transfusjonsmedisin Haukeland universitetssykehus og

Gades Institutt

Universitetet i Bergen

\section{Torvid Kiserud}

Institutt for klinisk medisin

Universitetet i Bergen

og

Seksjon for fostermedisin og ultralyd

Kvinneklinikken

Haukeland universitetssykehus

\section{Magne Børset}

Avdeling for immunologi og transfusjonsmedisin St. Olavs hospital

og

Det medisinske fakultet

Norges teknisk-naturvitenskapelige universitet

\section{Sturla Eik-Nes}

Nasjonalt senter for fostermedisin

St. Olavs hospital

og

Norges teknisk-naturvitenskapelige universitet

\section{Mirjana Arsenovic}

Avdeling for immunogi og transfusjonsmedisin Universitetssykehuset Nord-Norge

\section{Ganesh Acharya}

Kvinneklinikken

Universitetssykehuset Nord-Norge og

Universitetet i Tromsø

I svangerskapet kan mor immuniseres mot antigener på fosterets blodceller. Hvis antistoffene er av IgG-klasse, kan de passere placenta i det aktuelle eller senere svangerskap og indusere nedbryting av fosterets blodceller. Barnet kan påføres skade som kan være fatal eller gi livslange sekveler.

Immuniseringen kan ikke reverseres og er derfor en potensiell tragedie for en fertil kvinne og hennes barn. Tilstanden kan ikke oppdages eller påvirkes av kvinnen selv. Helsevesenet bør derfor til enhver tid være oppdatert på hvilke muligheter som finnes for å forebygge immunisering og behandle immuniserte gravide og deres barn og se til at kunnskapen utvikles og anvendes på godt grunnlag, både faglig og økonomisk.

\section{Ulike typer immunisering i svangerskapet \\ Immunisering mot erytrocytter}

Immunisering mot antigener på overflaten av erytrocytter kalles ofte blodtypeimmunisering.

En kvinne kan bli immunisert mot blodtypeantigener som hun selv mangler, og som fosteret har arvet fra far. Immuniseringen kan gi hemolyse av barnets erytrocytter (hemolytisk sykdom hos foster og nyfødt). Hemolysen kan føre til at barnet utvikler anemi, som kan føre til hydrops foetalis, som ubehandlet kan ha fatalt forløp (fig1). Før fødselen vil bilirubinet som frigjøres ved hemolysen, passere placenta og bli konjugert og utskilt av mor, men hos den nyfødte vil ukonjugert bilirubin akkumuleres fordi leveren ikke har tilstrekkelig konjugeringskapasitet. Ukonjugert bilirubin kan trenge inn i basalgangliene og gi varige nevrologiske skader.

Den hyppigste blodtypeimmuniseringen hos gravide skjer mot antigenet Rh(D), oftest i tilslutning til forløsningen (fig 2). Det er blant medisinens store triumfer at det er blitt mulig å forebygge flertallet av disse immuniseringene samt forutsi og diagnostisere føtal anemi med ikke-invasive teknikker (1) (fig 3) og behandle anemiske fostre med intrauterine transfusjoner styrt med ultralyd. Profylaksen består i at den Rh(D)negative kvinnen får injisert $1250-1500$
IU IgG anti-D intramuskulært innen 72 timer etter forløsning (vaginal eller keisersnitt) av Rh(D)-positivt barn, samt ved amniocentese, morkakebiopsi, antepartumblødning, traume mot abdomen, ytre vending, intrauterin fosterdød, spontan eller provosert abort og ved operasjon for ekstrauterint svangerskap. Hvordan anti-D virker, er fortsatt ikke fullgodt forklart, men effekten er slående. Statistikk fra tidligere Helseregion 2 (Øst- og Vestfold, Buskerud, Telemark, Aust- og Vest-Agder) samt Oslo viser at det før 1970 var 300-350 nye Rh(D)immuniseringer blant gravide i Norge per år. Etter at profylaksen ble innført i 1969, sank tallet raskt og var trolig 50-60 per år 1985 (2).

Mot andre blodtypeimmuniseringer finnes det ikke profylakse. Alle gravide med klinisk betydningsfulle antistoffer trenger utredning og oppfølging for å identifisere fostre med risiko for å utvikle anemi. Det innebærer utredning av fosterets Rh-status ved hjelp av blodprøve av mor og gjentatte ultralydundersøkelser som inkluderer dopplermålinger (fig 3). Slik følges en ev. utvikling av fosteranemi, og man kan finne det gunstigste tidspunktet for ultralydveiledet intrauterin transfusjon. I postnatalperioden omfatter behandlingsmulighetene lysbehandling, immunmodulering med høydose intravenøst gammaglobulin og utskiftingstransfusjon. Tilgjengelig statistikk tilsier at det oppdages 50-60 nyimmuniseringer mot andre blodtypeantigener enn $\mathrm{Rh}(\mathrm{D})$ hos gravide per år (2). I tillegg kommer tilfeller av hemolytisk sykdom der mor har blodtype $\mathrm{O}$ og barnet blodtype A eller B og mors preformerte IgG anti-A eller anti-B gir hemolyse postnatalt (ABO-uforlikelighet).

Kvinnen kan bli immunisert på tross av

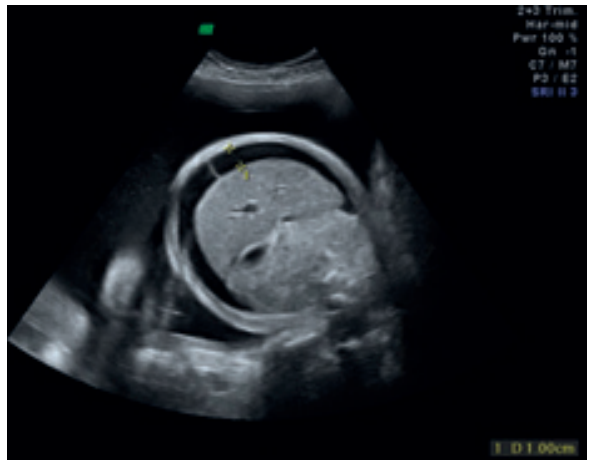

Figur 1 Ultralydbilde, tverrsnitt av føtal abdomen som viser ascites ved hydrops foetalis 


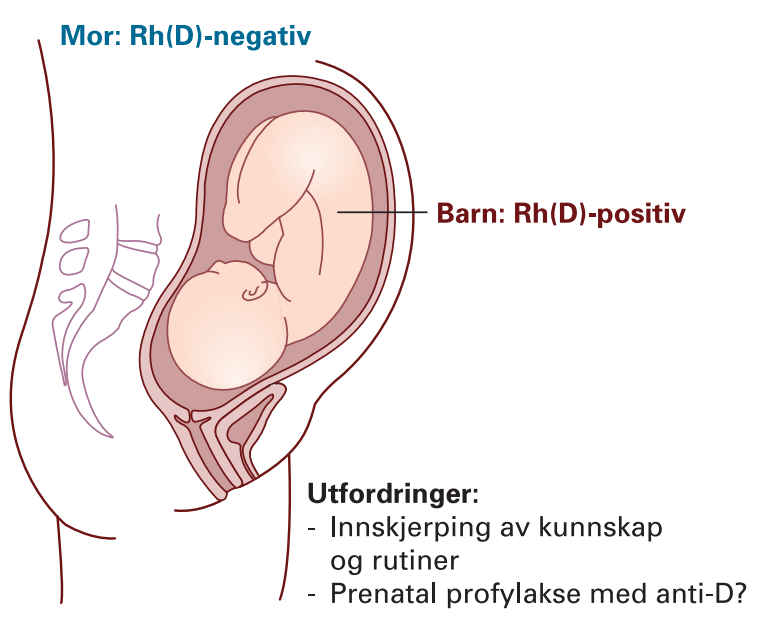

Figur 2 Rh(D)-negativ mor kan immuniseres mot antigenet $R h(D)$ på fosterets erytrocytter

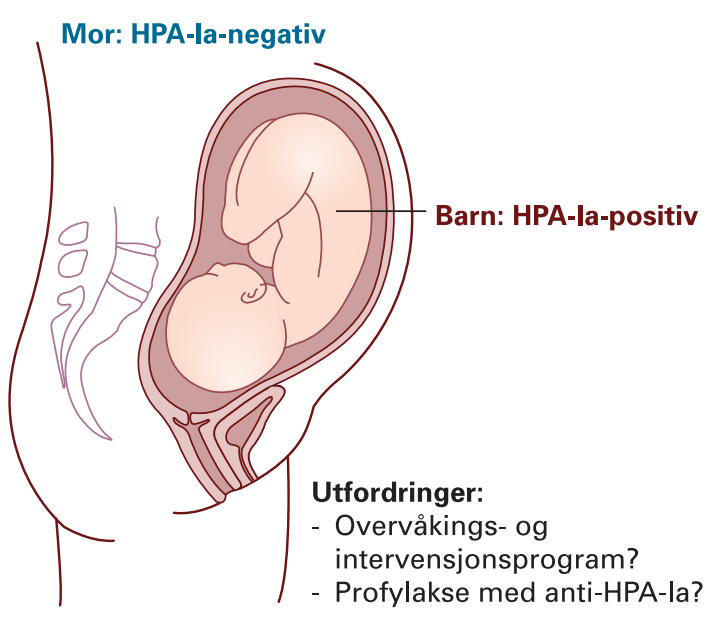

Figur 4 HPA-1a-negativ mor kan immuniseres mot antigenet HPA-1a på fosterets trombocytter adekvat anti-D-profylakse i de tilfellene det foreligger en større føtomaternell blødning enn anti-D-dosen kan blokkere. I Storbritannia anbefales det derfor å kvantitere føtale erytrocytter i mors sirkulasjon for å tilpasse IgG-dosen i forbindelse med fødselen (3). Vårt profylakseprogram tar heller ikke høyde for at føtomaternell blødning kan forekomme i hele siste trimester (4).

Nyere studier har vist at antall Rh(D)immuniseringer i svangerskap kan reduseres ytterligere ved å gi anti-D til $\mathrm{Rh}(\mathrm{D})$ negative kvinner i svangerskapsuke $28 \mathrm{og}$ 34 (5), med eller uten kjennskap til fosterets $\mathrm{Rh}(\mathrm{D})$-type. I Stockholm starter nå utprøvning av slik antenatal profylakse, etter forutgående $\mathrm{Rh}(\mathrm{D})$-typing av fosteret $\mathrm{i}$ blod-

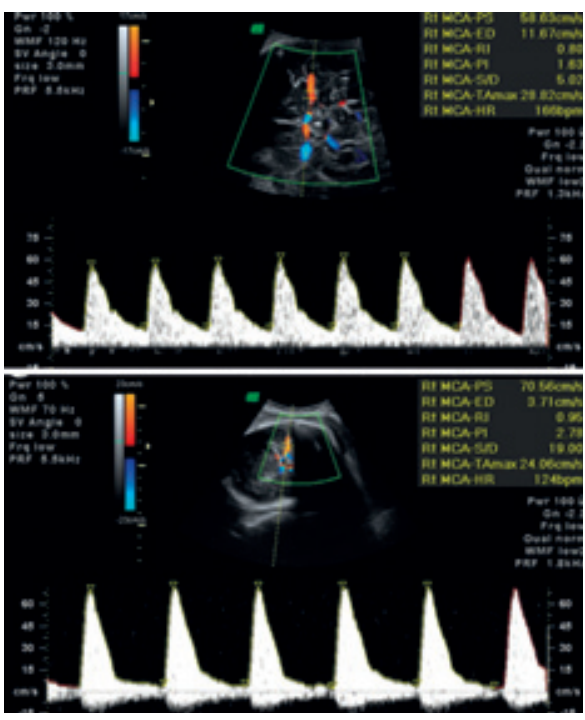

Figur 3 Dopplerundersøkelse av blodstrømshastighet $i$ a. cerebri media ved uke 32 fra normalt foster (øverst) og anemisk foster (nederst), med forhøyet systolisk maksimal strømningshastighet (> 1,5 g median verdi $i$ forhold til svangerskapsalder) prøve fra mor (M. Westgren, personlig meddelelse 2009). I Danmark innføres antenatal profyakse på nasjonalt nivå fra september 2009, også her med Rh(D)typing av fosteret $\mathrm{i}$ blodprøve fra mor i uke 25 (E. Taaning, personlig meddelelse 2009). Det har vært foreslått å gjennomføre dette også i Norge, men ingen beslutning er tatt.

Profylakse, kontroll og behandling for blodtypeimmunisering hos kvinner og hemolytisk sykdom hos foster og nyfødt involverer både primærhelsetjenesten, blodbanker, fødeavdelinger og barneavdelinger. For at profylaksen skal fungere effektivt, må alle ledd i programmet ha god kunnskap om tilstandens patofysiologi og om hvordan profylaksesystemet gjennomføres i praksis. Det dramatiske fallet $\mathrm{i}$ forekomsten av $\mathrm{Rh}(\mathrm{D})$-immuniseringer og av antallet tilfeller med hemolytisk sykdom kan imidlertid ha ført til at nye generasjoner av helsepersonell ikke har samme fokus på blodtypeimmuniseringer som i de første årene etter 1969. Vi har i de senere årene sett en rekke tilfeller av alvorlig blodtypeimmunisering i svangerskap og observert flere tilfeller av feilaktig anvendelse av anti-D. Vi har også erfart i praktisk arbeid at mange aktører i svangerskapsomsorgen ikke har tilstrekkelig kunnskap om blodtypeimmunisering og om profylakseprogrammet.

Mellom 1987 og 2001 ble det ikke ført statistikk over blodtypeimmuniseringer hos gravide i Norge. Senere statistikk viser for høye tall (6), bl.a. fordi flere blodbanker har inkludert funn etter passiv immunisering ved profylakse med anti-D. Det er heller ikke ført statistikk over sykelighet og dødelighet hos foster og nyfødt som følge av blodtypeimmunisering. Dette kan ha bidratt ytterligere til å fjerne fokus fra disse tilstandene og gjør at man for tiden ikke har tilstrekkelig oversikt over forekomst og behandlingseffekt.

\section{Immunisering mot trombocytter}

Immunisering av mor mot trombocyttantigener kan gi trombocytopeni hos barnet (føtal-neonatal alloimmun trombocytopeni) (fig 4), med død eller hjerneblødning med varige nevrologiske skader som de mest fryktede konsekvensene. Immunisering mot trombocytter skjer sjeldnere enn mot erytrocytter, bl.a. fordi færre kan immuniseres (ca. $2 \%$ mangler det klinisk viktigste trombocyttantigenet, HPA-1a, mens $15 \%$ mangler $\mathrm{Rh}(\mathrm{D})$-antigenet), men konsekvensene kan være like alvorlige.

Nylig undersøkte man i en stor norsk studie forekomsten av føtal-neonatal alloimmun trombocytopeni i Norge og effekten av overvåking og intervensjon med elektiv sectio og tilgang til forlikelige trombocytter (7). Prøvetakingen ble synkronisert med prøvetakingen for $\mathrm{Rh}(\mathrm{D})$-overvåking, og den gravide ble i alminnelighet ikke utsatt for flere prøvetakinger enn ellers. Studien sannsynliggjør at et slikt program kan redusere risikoen for alvorlige komplikasjoner ved denne tilstanden, og at programmet er helseøkonomisk lønnsomt (8). Det har imidlertid vært reist kritikk mot studien fordi den ikke har et eget kontrollmateriale, i stedet sammenliknet man resultatene med forekomsten i tidligere publiserte prospektive studier (9).

Foreløpig finnes det ingen mulighet for å forebygge immunisering mot trombocyttantigener. Imidlertid er det vist at omkring tre firedeler av immuniseringene skjer i tilslutning til forløsningen (10). Det er derfor tenkelig at flertallet av immuniseringene mot antigenet HPA-1a kan forebygges ved å gi IgG anti-HPA-1a til HPA-1a-negative kvinner etter forløsningen, på samme måte som den etablerte profylaksen mot $\mathrm{Rh}(\mathrm{D})$-immunisering. Forskere som var sentralt involvert i den norske studien (7) er nå i gang med å utvikle slik immuniserings- 
profylakse med anti-HPA-1a (B. Skogen, personlig meddelelse 2009).

Immunisering mot nøytrofile granulocytter Immunisering av mor mot antigener på barnets granulocytter kan gi nøytropeni hos den nyfødte og dermed alvorlige infeksjoner (neonatal alloimmun nøytropeni). Tilstanden er selvbegrensende i tid, men vil vedvare så lenge de aktuelle antistoffene har tilstrekkelig konsentrasjon. Langt mindre forskning er utført om immunisering mot granulocytter enn mot erytrocytter og trombocytter, og det er foreløpig intet program for diagnostikk eller overvåking av slik granulocyttimmunisering i Norge eller noe annet land.

\section{Diskusjon}

For blodtypeimmunisering og hemolytisk sykdom hos foster og nyfødt er det vist at programmet for profylakse, overvåking og ev. elektive inngrep gir stor helsegevinst. Med prenatal profylakse med anti-D kan trolig forekomsten av immunisering mot $\mathrm{Rh}$ (D) reduseres ytterligere. Det er imidlertid bekymringsfullt at man ikke har god oversikt over nåværende forekomst av blodtypeimmuniseringer og hemolytisk sykdom hos foster og nyfødt, og at kunnskapen om disse tilstandene og om det etablerte profylakseprogrammet trolig ikke er god nok hos alt personell i svangerskapsomsorgen. Det er derfor nødvendig med målrettet revisjon av programmet, strukturert undervisning av personell både i primærhelsetjenesten og i sykehus, og evaluering av prenatal profylakse med anti-D. $\AA$ gjennomføre denne oppgraderingen omkring immunisering representerer en stor utfordring for det norske fagmiljøet innen svangerskapsomsorg.

Det har nylig vært hevdet at det foreligger tilstrekkelig dokumentasjon til å innføre program også for overvåking og intervensjon ved føtal-neonatal alloimmun trombocytopeni som en del av den rutinemessige svangerskapsomsorgen (11). De formelle manglene ved den norske studien $(7,9)$ gjør at resultatene alene neppe kan rettferdiggjøre et slikt tiltak, og andre stu- dier av tilsvarende omfang og kvalitet finnes ikke.

Selv om den norske studien ikke gir endelig svar, er dataene etter vår oppfatning så sterke at spørsmålet om overvåkings- og intervensjonsprogrammets betydning bør bli gjenstand for en medisinsk teknologiutprøvning med vitenskapelig uangripelig kontrollmateriale. En slik utprøvning er under planlegging som nordisk samarbeid (J. Kjeldsen-Kragh, personlig meddelelse 2009). Dette forutsetter samarbeid mellom alle ledd i den norske svangerskapsomsorgen. Sentrale helsemyndigheter vil måtte gå god for den ved å tillate at undersøkelse på trombocyttimmunisering tilbys alle gravide $i$ landet $i$ en begrenset periode. En slik utprøvning vil også være en forutsetning for profylakseutprøvning.

Norge er allerede $i$ fremste rekke internasjonalt innenfor forskningen om trombocyttimmunisering i svangerskap, mens det lenge har vært mangel på god forskning om blodtypeimmunisering. Et tilleggsargument for å gjennomføre utprøvning av overvåkings- og intervensjonsprogrammer for trombocyttimmunisering i svangerskap er derfor at den gjennom nasjonalt samarbeid vil virke inspirerende og vitaliserende på all forskning og utvikling innenfor immunisering i svangerskapet i Norge. Dette vil virke positivt på evnen til også å gjennomføre revisjon og oppgradering av programmet for forebygging av $\mathrm{Rh}(\mathrm{D})$-immunisering og overvåking og behandling av hemolytisk sykdom hos foster og nyfødt.

\section{Forslag til tiltak}

Norsk svangerskapsomsorg er ikke optimalisert $i$ takt med dagens kunnskap med henblikk på immunisering. Det trengs et nytt nasjonalt faglig samarbeid for å oppgradere programmet for immunisering mot $\mathrm{Rh}(\mathrm{D})$ og mot andre blodtypeantigener. Overvåking, forebygging og behandling av føtalneonatal trombocytopeni bør gjøres til gjenstand for videre systematisk utprøvning og utvikling. Den etablerte kompetansen innen trombocytopeni er en naturlig drivkraft for forskning og utvikling i hele fagområdet. Samarbeidet kan ledes av en nasjonal sam- arbeidsgruppe innen immunisering i svangerskapet, forankret i Helsedirektoratet og med oppgave å samordne forskningsaktivitet, kvalitetssikring, opplæring og informasjon på nasjonalt nivå.

Oppgitte interessekonflikter: Hans Erik Heier er avdelingsoverlege ved Avdeling for immunologiog transfusjonsmedisin, der noen av medarbeiderne har vært involvert i forskning om føtal-neonatal alloimmun trombocytopeni. Han er ikke selv involvert $i$ disse prosjektene. De andre forfatterne har ingen oppgitte interessekonflikter.

\section{Litteratur}

1. Mari G, Deter RL, Carpenter RL et al. Noninvasive diagnosis by Doppler ultrasonography of fetal anemia due to maternal red-cell alloimmunization. N Engl J Med 2000; 342: 9-14.

2. Kornstad L. Fifteen years' experience with postpartum Rh prophylaxis in Norway (1969-83): incidence of new cases of anti-D and other clinically important blood group antibodies in pregnant women. NIPH Ann 1987; 10, nr. 1: 3-10.

3. Royal College of Obstetricians and Gynaecologists www.rcog.org.uk/womens-health/clinicalguidance/use-anti-d-immunoglobulin-rhprophylaxis-green-top-22 (9.6.2009).

4. Hughes RG, Craig JI, Murphy WG et al. Causes and clinical consequences of Rhesus (D) haemolytic disease of the newborn: a study of a Scottish population, 1985-1990. Br J Obstet Gynaecol 1994; 101 297-300.

5. Crowther C. Anti-D administration after childbirth for preventing rhesus alloimmunisation (Cochrane review). I: The Cochrane Library. Chichester, UK: John Wiley, 2003.

6. Norges Røde Kors Blodprogram. Blodtransfusjonstjenesten i Norge: Statistikk 2001 -7. Oslo: Norges Røde Kors, 2002-8.

7. Kjeldsen-Kragh J, Killie MK, Tomter $G$ et al. A screening and intervention program aimed to reduce mortality and serious morbidity associated with severe neonatal alloimmune thrombocytopenia. Blood 2007; 110: 833-9.

8. Killie MK, Kjeldsen-Kragh J, Husebekk A et al. Cost-effectiveness of antenatal screening for neonatal alloimmune thrombocytopenia. BJOG 2007. 114: 588-95.

9. Fretheim A. Kritikk av norsk screeningstudie Tidsskr Nor Legeforen 2008; 128: 2617.

10. Killie MK, Husebekk A, Kjeldsen-Kragh J et al. A prospective study of maternal anti-HPA 1a antibody level as a potential predictor of alloimmune thrombocytopenia in the newborn. Haematologica 2008; 93: 870-7.

11. Tiller H. Kritisk søkelys på norsk screeningstudie. Tidsskr Nor Legeforen 2008; 128: 1982-4.

Manuskriptet ble mottatt 4.2. 2009 og godkjent 2.7. 2009. Medisinsk redaktør Anne Kveim Lie. 